\title{
Stability and toxicity of Clostridium perfringens type D epsilon prototoxin treated by iodine
}

[Estabilidade e toxicidade da protoxina epsilon de Clostridium perfringens tipo D]

\author{
P.H. Rocha ${ }^{1}$, R.A. Assis $^{2}$, F.C.F. Lobato ${ }^{3}$, V.N. Cardoso ${ }^{4}$, L.G.D. Heneine ${ }^{5 *}$ \\ ${ }^{1}$ Aluno de pós-graduação - FF-UFMG - Belo Horizonte, MG \\ ${ }^{2}$ Lanagro-MG - MAPA - Pedro Leopoldo, MG \\ ${ }^{3}$ Escola de Veterinária - UFMG - Belo Horizonte, MG \\ ${ }^{4}$ Faculdade de Farmácia - UFMG - Belo Horizonte, MG \\ ${ }^{5}$ Fundação Ezequiel Dias \\ Rua Conde Pereira Carneiro, 80 \\ 30510-010 - Belo Horizonte, MG
}

\begin{abstract}
Purified epsilon prototoxin of Clostridium perfringens type D was produced, purified, and detoxified by the stoiechiometric method of non-radioactive iodine incorporation. Different degrees of iodination were perfomed and the toxicity of the derivatives were analysed by in vivo studies. Toxicity decreased inversely to the iodine incorporation. Eletrophoretic analysis showed different levels of stability of samples kept under different temperatures $4^{\circ} \mathrm{C},-20^{\circ} \mathrm{C}$, and $-80{ }^{\circ} \mathrm{C}$. The iodinated prototoxins were stocked for a period of four months.
\end{abstract}

Keywords: Clostridium perfringens, epsilon toxin, iodination, stability

\section{RESUMO}

A prototoxina epsílon de Clostridium perfringens tipo D foi produzida, purificada e destoxificada por estoiquiometria. Diferentes quantidades de iodo foram incorporadas à estrutura protéica da prototoxina e a toxicidade dos derivados foi analisada em estudos in vivo. Verificou-se que a toxicidade diminuiu à medida que os átomos de iodo foram incorporados à prototoxina. A análise eletroforética demonstrou a estabilidade das amostras quando armazenadas $a 4^{\circ} \mathrm{C},-20^{\circ} \mathrm{C}$ e $-80^{\circ} \mathrm{C}$. A prototoxina iodada foi estocada por um período de quatro meses.

Palavras-chave: Clostridium perfringens, toxina epsílon, iodação, estabilidade

\section{INTRODUCTION}

The epsilon toxin is produced by the Clostridium perfringens types $\mathrm{B}$ and $\mathrm{D}$ in a relatively inactive form called epsilon prototoxin (Rood and Cole, 1991; Payne and Oyston, 1997). After activation in the intestinal tract, this prototoxin promotes a rapid fatal enterotoxemia in caprines and ovines (Songer, 1997). Calves are also susceptible to the epsilon prototoxin, with lesions in the lungs and central nervous system (Uzal et al., 2002).
Occasionally, adult cattle and horses can be affected too (Finnie, 2004).

The enterotoxemy caused by clostridia epsilon prototoxins can results in mortality rates as high as $100 \%$, leading considerable economic losses to farmers (Rood and Cole, 1991; Payne and Oyston, 1997; Assis et al., 2001). The control and prophylaxis should be based on the good management and vaccination of all the herd due to their permanent contact with Clostridium,

Recebido em 3 de janeiro de 2008

Aceito em 21 de julho de 2008

*Autor para correspondência (corresponding author)

E-mail: heneinel@funed.mg.gov.br

Apoio: FAPEMIG/CNPq 
present in the intestinal tract and soil (Lobato and Assis, 2001).

For diseases in which the toxin is the sole responsible for the pathology, the vaccine can only be composed of the toxoid (Playfair, 1999). The toxoid should be capable of inducing a protective immune response, with the diphteric and tetanus vaccine being examples of success (Abbas et al., 2003).

A method for the inactivation of toxins is the detoxification by the controlled incorporation of iodine. The cationic iodine atoms substitutes the $\mathrm{H}^{+}$on the aromatic rings of histidine and tyrosine residues. This process is stoichiometric and irreversible under physiologic conditions, and with little modifications of the molecular structure of the derivatives. The immunogenicity is preserved and no adverse effects are induced by the modified molecule (Heneine et al., 1986; Heneine and Heneine, 1998).

This study proposes an alternative method for the production of toxoids, free of contaminants, stable, and nontoxic, to be employed in the development of new vaccines for the prophylaxis of the fatal enterotoxemy, caused by the epsilon toxin of $C$. perfringens types $\mathrm{B}$ and $\mathrm{D}$. This is necessary since most vaccines against clostridials produced in Brazil are based on concentrated culture medium with low level of purification containing large number of components nonspecific for the desired immunogenicity. Problems of low immunogenicity, stability and high reactogenicity are often observed (Lobato and Assis, 2001).

\section{MATERIALS AND METHODS}

Samples of $C$. perfringens type $\mathrm{D}$, donated by the INTA - Argentina, were used for the production and purification of the epsilon prototoxin as described in Parreiras et al. (2002) and Carvalho et al. (2006).

The epsilon prototoxin was detoxified as described in Heneine et al. (1986) and Heneine and Heneine (1998). Briefly to $2 \mathrm{mg}$ of prototoxin dissolved in $10 \mathrm{ml}$ of $0.1 \mathrm{M}$ phosphate buffer $\mathrm{pH}$ 8.2 , aliquots of $12 \mu \mathrm{l}$ of $40 \mathrm{mM} \mathrm{KI}_{3}$ were added at 5 min intervals with constant shaking in an ice bath. After a number of additions, the toxin solution became yellow indicating saturation of iodine incorporation and the presence of free iodine in the solution. At that point, the solution was kept under gentle shaking for $1 \mathrm{~h}$ after then $3 \mu \mathrm{l}$ of the solution was added to $3 \mu \mathrm{l}$ of a $1 \%$ $(\mathrm{w} / \mathrm{v})$ starch solution. When the mixture turned to a blue color, the addition of iodine was stopped and the prototoxin solution was considered saturated with iodine. The volume of $\mathrm{KI}_{3}$ added was recorded and used as the amount needed to achieve a $100 \%$ incorporation of iodine to a solution containing $2 \mathrm{mg}$ of the epsilon prototoxin.

To evaluate the toxicity of the iodinated prototoxin, an aliquot was activated with a trypsin solution at $1 \mathrm{mg} / \mathrm{ml}$ used in a proportion of $10 \mu \mathrm{l}$ to each $1 \mathrm{ml}$ of the prototoxin solution and incubated for $30 \mathrm{~min}$ at $37^{\circ} \mathrm{C}$. After activation, volumes containing 25 mice $\mathrm{LD}_{50}$ were diluted to $0.2 \mathrm{ml}$ with $0.1 \mathrm{M}$ PBS $\mathrm{pH} 7.2-7.4$ and injected in Swiss female mice weighting 18$22 \mathrm{~g}$ by the intravenous (IV) route. Mortality was recorded up to $72 \mathrm{~h}$. To prepare $2 \mathrm{mg}$ of prototoxin solutions containing different levels of iodine incorporation, different volumes of $40 \mathrm{mM} \mathrm{KI}_{3}$ were added corresponding to 0,20 , $40,60,80$, and $100 \%$ of the $120 \mu \mathrm{l}$ previously observed as the $100 \%$ saturation volume. The solutions were named proE- $0 \%$, proE- $20 \%$, proE- $40 \%$, proE- $60 \%$, proE- $80 \%$, and proE$100 \%$, respectively. The proE- $0 \%$ received no $\mathrm{KI}_{3}$ and served as the positive control.

The toxicity of the prototoxin containing different amounts of incorporated iodine atoms (i.e. proE $0 \%$ to proE100\%) were tested in mice as described previously. All samples were activated and doses corresponding to 25 and $100 \mathrm{LD}_{50}$ diluted to a final volume of $0.2 \mathrm{ml}$ in $0.1 \mathrm{MPBS} \mathrm{pH} 7.4$ were injected by the IV route in female Swiss mice weighting around $18-22 \mathrm{~g}$, being four mice per dose. Deaths were recorded up to $72 \mathrm{~h}$. All experiments were approved by the Ethics Committee Animal Experimentation ${ }^{1}$.

The stability of the native and the detoxified prototoxins was assayed by SDS-PAGE. Aliquots of $100 \mu \mathrm{l}$ of the samples, native and proE- $20 \%$ to proE- $100 \%$ were kept in the dark for 120 days at temperatures of $4^{\circ} \mathrm{C},-20^{\circ} \mathrm{C}$ and $-80^{\circ} \mathrm{C}$. After this period, all samples were electrophoresed (Laemmli, 1970) and silver stained (Tunon and Johanson, 1984).

${ }^{1}$ CETEA/UFMG - Protocolo $\mathrm{n}^{\circ}$ 51/2006. 


\section{RESULTS AND DISCUSSION}

An aliquot of the supernatant of the $C$. perfringens culture activated by trypsin showed toxicity when injected in mice (result not shown). The purification of the epsilon toxin from the supernatant involved a DEAESepharose chromatography. The first eluted peak contained the purified toxin. Fig. 1, lane 1 shows the purified native toxin with an approximate molecular weight of $32.7 \mathrm{kDa}$ in accordance with previously published data (Habeed, 1975; Payne and Oyston, 1997 ).

The iodination of the prototoxin up to the saturation level resulted in a loss of its toxicity after activation with tripsin. The results showed that $120 \mu \mathrm{l}$ of a $40 \mathrm{mM} \mathrm{KI}_{3}$ solution $\mathrm{pH} 8.2$ detoxified $2 \mathrm{mg}$ of epsilon prototoxin. To assess the remaining toxicity, mice received $25 \mathrm{LD}_{50}$ of the toxoid, activated by trypsin by the IV route and did not develop any sign of intoxication up to $72 \mathrm{~h}$. Control mice that received the same dose of native activated toxin died within $12 \mathrm{~h}$ (result not shown). This result is in accordance with previous reports of iodination of different toxins and venoms, such a choleric, tetanic, and the TxTs toxin from the scorpion Tityus serrulatus (Heneine et al., 1986; Heneine and Heneine, 1998).

The electrophoretic profiles were relatively unchanged for the prototoxin derivatives that had different amounts of incorporated iodine when compared to that of the native prototoxin (Fig. 1).

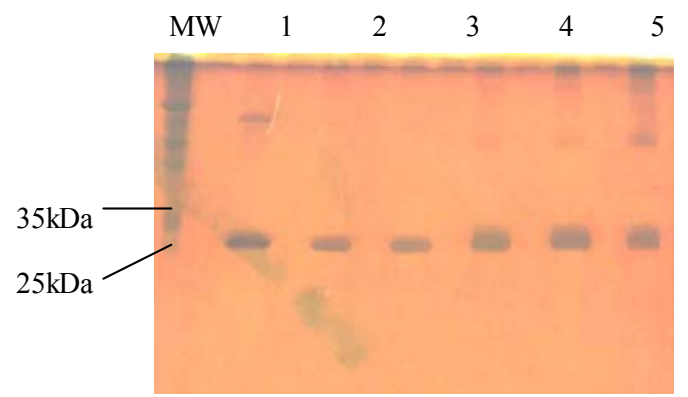

Figure 1. SDS-PAGE eletrophoretic profile of the epsilon prototoxin with different levels of incorporated iodine - 1: proE- $0 \%, 2$ : proE- $20 \%, 3$ : proE- $40 \%, 4$ : proE- $60 \%, 5$ : proE- $80 \%$, and 6: proE- $100 \%$.

The stoichiometric incorporation of iodine at 0 , $20,40,60,80$, and $100 \%$ levels showed that the decrease in toxicity of the derivatives is directly proportional to the amount of incorporated iodine. After $60 \%$ incorporation, toxicity was completely abolished, even after a challenge of $100 \mathrm{LD}_{50}$ in mice (Table 1).

Table 1. Toxicity assay of the prototoxin derivatives with different amounts of iodine incorporation

\begin{tabular}{ccc}
\hline Samples of & \multicolumn{2}{c}{$\%$ mortality } \\
\cline { 2 - 3 } epsilon prototoxin & $25 \mathrm{LD}_{50}$ & 100LD $_{50}$ \\
\hline ProE-0\% & 100 & 100 \\
ProE-20\% & 75 & 100 \\
ProE-40\% & 50 & 75 \\
ProE-60\% & 0 & 0 \\
ProE-80\% & 0 & 0 \\
\hline
\end{tabular}

Death was recorded up to $72 \mathrm{~h}(\mathrm{n}=4)$.

SDS-PAGE was used to assess the stability of the prototoxin and its iodinated derivatives up to $80 \%$, stored for 120 days under different temperatures. No significant change was observed on the electrophoretic migration of the iodinated samples when compared to the native prototoxin, Figure 2 A-C. The samples with higher levels of incorporated iodine showed a more diffuse pattern, Figure $2 \mathrm{~B}-\mathrm{C}$, lanes 4 to 5 .

The native prototoxin proE-0 \% was stable when kept at $-20{ }^{\circ} \mathrm{C}$ and $-80{ }^{\circ} \mathrm{C}$ for a period of 120 days. However, there was a considerable denaturation when kept at $4{ }^{\circ} \mathrm{C}$, depicted by the strong low molecular weight band on lane 1 (Fig. 2A). The iodinated prototoxins proE- $40 \%$ to proE- $80 \%$ also showed low molecular weight bands indicating denaturation (Fig.2A-C). The proE-20\% showed a more stable electrophoretic pattern throughout the storage period. The toxicity of the stored toxoids was not tested.

In this study, a highly purified prototoxin was obtained (Fig. 1) with a molecular weight near $32.7 \mathrm{kDa}$, similar to the previously described (Habeed, 1975; Tunon and Johanson, 1984). The purified $C$. perfringens epsilon prototoxin was detoxified by the stechiometric method of protein iodination. The loss of toxicity of the iodinated prototoxin was directly proportional to the amount of incorporated iodine. The electrophoretic pattern of the iodinated prototoxin derivatives remained similar to that of the native prototoxin. This result indicates the preservation of the molecular structure of the derivatives. 


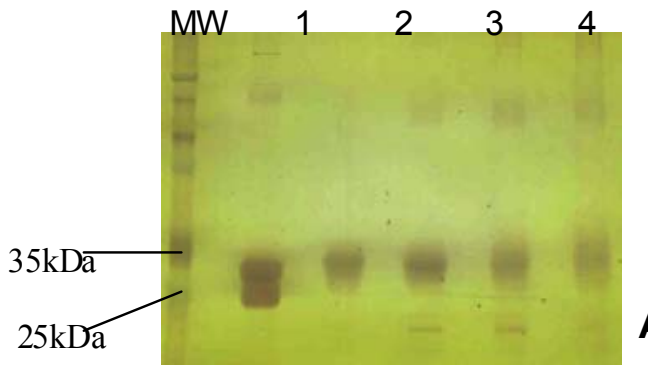

A
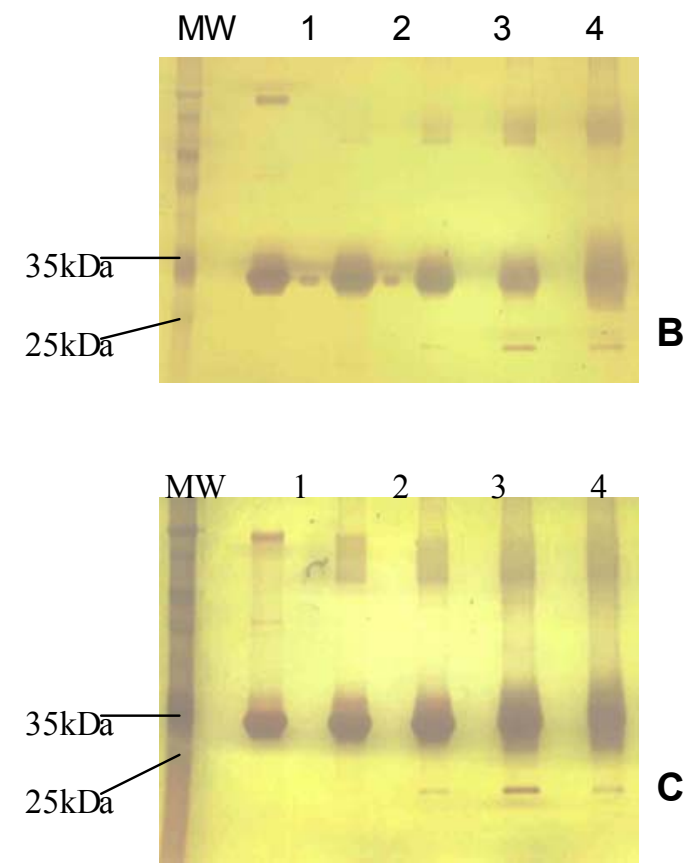

Figure 2. SDS-PAGE eletrophoretic profile of the samples proE- $0 \%$ (1), proE- $20 \%$ (2), proE- $40 \%$ (3), proE-60\% (4), and proE- $80 \%$ (5) kept at $4^{\circ} \mathrm{C}(\mathrm{A})$, $20^{\circ} \mathrm{C}(\mathrm{B})$, and $-80^{\circ} \mathrm{C}(\mathrm{C})$ for 120 days.

Hence, the controlled iodination of the epsilon enterotoxin of $C$. perfringens type D could pose as a method of choice for the preparation of toxoids regarding the production of vaccines.

\section{REFERENCES}

ABBAS, A.K.; LICHTMAN, A.H.; POBER, J.S. Cellular and Molecular Immunology. 4.ed. Philadelphia: W.B. Sawnders, 2003. 553p.

ASSIS, R.A.; DIAS, L.D.; PARREIRAS, R.A. et al. Principais clostridioses dos ruminantes. Rev. CFMV , n.22, p.49-56, 2001.

CARVALHO, A.V.A.; HENEINE, L.G.D.; ASSIS, R.A. et al. Production and purification of beta-toxin from Clostridium perfringens type C. Arq. Bras. Med. Vet. Zootec., v.58, p.276-278, 2006
FINNIE, J.W. Neurological disorders produced by Clostridium perfringens type D epsilon toxin. Anaerobe, v.10, p.145-150, 2004.

HABEED, A.F.S.A. Studies on epsilon prototoxin of Clostridium perfringens type D physicochemical and chemical properties of epsilon prototoxin. Bioch. Biophys. Acta, v.412, p.62-69, 1975.

HENEINE, L.G.D.; CARDOSO, V.N.; DANIEL, J.P. et al. Detoxifcation of the $\mathrm{T}_{2}$ fraction from scorpion (Tityus serrulatus, Lutz and Mello) venom by iodination and some immunogenic properties of the derivatives. Toxicon, v.24, p.501-505, 1986

HENEINE, L.G.D.; HENEINE, I.F. Stepwise iodination. A general procedure for detoxification of proteins suitable for vaccine development and antiserum production (Review). Biol., v.26, p.25-32, 1998.

LAEMMLI, U.K. Cleavage of structural proteins during the assembly of the head of bacteriophage T4. Nature, v.227, p.680-686, 1970.

LOBATO, F.C.F.; ASSIS, R.A. Diagnóstico de clostridioses e controle de qualidade das vacinas. In: CONGRESSO BRASILEIRO DE BUIATRIA, 4., 2001, Campo Grande. Anais... Campo Grande, 2001. p.45-52.

PARREIRAS, P.M.; LOBATO, F.C.F.; HENEINE, L.G.D. et al. Production and purification of epsílon prototoxin produced by C. perfringens type D. Arq. Bras. Med. Vet. Zootec., v.54, p.328-330, 2002.

PAYNE, D.; OYSTON, P. The Clostridium perfringens epsilon toxin. In: ROOD, J.I.; McCLANE, B.A.; SONGER, J.G. et al. (Eds). The clostridia: molecular biology and pathogenesis. London: Academic, 1977. p.439-447.

PLAYFAIR, J. Vacinação. In: ROITT, J.; BROSTOFF, J.; MALE, D. (Eds). Imunologia, 5.ed. São Paulo: Manole, 1999. p.263-272.

ROOD, J.I., COLE, S.T. Molecular genetics and pathogenesis of Clostridium perfringens. Am. Soc. Microbiol., v.55, p.621-648, 1991.

SAKURAI, S.; NAGAHAMA, M. OCHI, S. Major toxins of Clostridium perfringens. J. Toxicol., v.16, p.195-214, 1997.

SONGER, J.G. Clostridial diseases of animals. In: In: ROOD, J.I.; McCLANE, B.A.; SONGER, J.G. et al. (Eds). The clostridia: molecular biology and pathogenesis. London: Academic, 1977. p.153-182.

TUNON, P., JOHANSON, K.E. Yet another improved silver staining method for the detection of proteins in poliacrylamide gels. J. Biochem. Biophys. Meth., v.9, p.171-179, 1984.

UZAL, F.A.; KELLY, W.R.; MORRIS, W.E. et al. Effects of intravenous injection of Clostridium perfringens type D epsilon toxin in calves. J. Comp. Path., v.126, p.71-75, 2002. 